\title{
Yield Improvement of Kharif Rice by Different Weed Management Practices
}

\author{
Nirmala Patel* and Pritam Ghosh \\ Department of Agronomy, Palli Siksha Bhavana, Visva-Bharati, West Bengal, India \\ *Corresponding author
}

\begin{tabular}{|l|}
\hline Ke y w or d s \\
$\begin{array}{l}\text { Pyrazosulfuron } \\
\text { ethyl, Hand } \\
\text { weeding, Weed } \\
\text { management, Rice }\end{array}$ \\
\hline Article Info \\
\hline $\begin{array}{l}\text { Accepted: } \\
\text { 04 February } 2019 \\
\text { Available Online: } \\
\text { 10 March } 2019\end{array}$ \\
\hline
\end{tabular}

\section{Introduction}

Rice is the world's most important staple food crop for more than half of the world's population, occupying a prime place after wheat and is the main source of carbohydrate, protein and calories for a large section of the population. Globally, rice occupies an area of 147 million hectares with production of 525 million tonnes. In India, it is produced in an area of 46.19 million hectares with a production of 106.29 million tonnes and productivity of $2462 \mathrm{~kg} \mathrm{ha}^{-1}$.

Rice is cultivated in a very wide range of ecosystems from irrigated to shallow lowlands, mid-deep lowlands and deep water to uplands. Transplanting in puddled soil with continuous flooding is the major method of rice cultivation in India. Weed infestation is one of the serious constraints in rice production. Weed affects rice by competing 
for nutrient, light, water and space accounting nearly one third of crop loss. Transplanted rice crop faces diverse type of weed flora, consisting of grasses, sedges and some broadleaf weeds, which reduces yield up to 48 per cent with an annual loss of 15 million tonnes due to weed competition. Prevention of weed competition and provision of weed free environment at critical period of rice growth is necessary for successful rice production (Murali and Gowthami, 2017). Most transplanted rice growers in India mechanically weed their crops two or three times per season (Rodder, 2001) raising cost of labour and their non-availability in time lead to the search for alternative methods. Herbicides offer the most effective, economical and practical way of weed management (Sureshkumar and Durairaj, 2016). So, there is a need to evaluate the effect of new herbicides on growth of transplanted rice for providing wider options to farmers.

\section{Materials and Methods}

A field experiment, "Weed management in transplanted kharif rice (Oryza sativa L.)" was conducted in Block-A, Plot no- 2 of the Agricultural Farm of Palli Siksha Bhavana, Visva-Bharati, Sriniketan during kharif season of 2017 to study the effect of different weed management practices on growth of transplanted kharif rice. The experiment was laid out in RBD design with nine treatments and three replications. The net plot size was 5 $\mathrm{m} \times 4 \mathrm{~m}$. The fertilizers were applied considering 80:40:40 kg of $\mathrm{N}: \mathrm{P}_{2} \mathrm{O}_{5}: \mathrm{K}_{2} \mathrm{O}$ per ha as recommended dose as urea, single superphosphate and murate of potash, respectively.

The experimental site was sandy loam with acidic $\mathrm{pH}(5.36), \mathrm{EC}\left(0.61 \mathrm{dSm}^{-1}\right)$, medium in organic carbon $(0.57 \%)$, available $\mathrm{N}(385 \mathrm{~kg}$ $\left.\mathrm{ha}^{-1}\right), \mathrm{P}_{2} \mathrm{O}_{5}\left(23.4 \mathrm{~kg} \mathrm{ha}^{-1}\right)$ and $\mathrm{K}_{2} \mathrm{O}(191 \mathrm{~kg}$ $\mathrm{ha}^{-1}$ ). Rice seeds were sown first in nursery and after 21 days they were uprooted and transplanted in the main field at the rate of 7 $\mathrm{kg} \mathrm{ha}^{-1}$ by following $20 \mathrm{~cm} \mathrm{x} 15 \mathrm{~cm}$ spacing on $16^{\text {th }}$ July 2017 . The rice variety used was MTU-1010.

The Treatments consisted of $T_{1}=$ Pretilachlor $500 \mathrm{~g} / \mathrm{ha}$ as pre emergence, $\mathrm{T}_{2}=$ Oxadiargyl 90 $\mathrm{g} / \mathrm{ha}$ as pre emergence, $\mathrm{T}_{3}=$ Pyrazosulfuron ethyl $25 \mathrm{~g} / \mathrm{ha}$ as pre emergence, $\mathrm{T}_{4}=$ Pretilachlor $500 \mathrm{~g} / \mathrm{ha}$ as PE followed by hand weeding at $40 \mathrm{DAT}, \mathrm{T}_{5}=$ Oxadiargyl 90 $\mathrm{g} / \mathrm{ha}$ as PE followed by hand weeding at 40 DAT, $\mathrm{T}_{6}=$ Pyrazosulfuron ethyl $25 \mathrm{~g} / \mathrm{ha}$ as PE followed by hand weeding at $40 \mathrm{DAT}, \mathrm{T}_{7}=$ Hand weeding twice at 20 DAT and 40 DAT, $\mathrm{T}_{8}=$ Weed free, $\mathrm{T}_{9}=$ Unweeded control. The pre emergence herbicides were applied at 3 DAT as sand mix application through knap sack sprayer using a spray volume of $500 \mathrm{~L} \mathrm{ha}^{-1}$.

Weed density and weed dry weight were recorded at 20, 40, 60 DAT. At each sampling time, two quadrates of $50 \mathrm{~cm} \times 50 \mathrm{~cm}$ were placed randomly in each plot and weeds were collected from each quadrate and converted to numbers per $\mathrm{m}^{2}$. Weeds were uprooted, washed with tap water, sundried, oven-dried at $65{ }^{\circ} \mathrm{C}$ for 48 hours. After attaining the constant weight, the samples were weighed and the weed dry weight was expressed in grams per $\mathrm{m}^{2}$. The square-root transformation of original data of weeds was done for statistical analysis as described by Cochran and Cox (1957).

The growth parameters like plant height, leaf area index (LAI), dry matter accumulation and Crop Growth Rate (CGR) were recorded at 20, 40, 60 DAT. Yield data recorded after the harvest of rice crop. Collected data were analyzed statistically and the means were separated by least significant difference (LSD) test. 


\section{Results and Discussion}

\section{Effect of weed management on dry weight of weeds}

The data presented in Table 1 on dry weight of weeds revealed that all the weed control treatments reduced the weed dry weight significantly from that of unweeded treatment. The weed free treatment registered the lowest dry weight of weeds $\left(0.71 \mathrm{~g} / \mathrm{m}^{2}\right)$. Among the weed control treatments, the lowest weed dry weight were registered in Pyrazosulfuron ethyl $25 \mathrm{~g} / \mathrm{ha}$ as preemergence $f b$ hand weeding at 40 DAT at 20 DAT and 60 DAT. It was closely followed by Hand weeding at 20 and 40 DAT. All other weed control treatments did not differ significantly from Pyrazosulfuron ethyl $25 \mathrm{~g} / \mathrm{ha}$ as pre-emergence $f b$ hand weeding at 40 DAT at 20 DAT and 60 DAT. The highest weed dry weight recorded with unweeded check for all the stages $(4.89,13.74,16.52$ $\mathrm{g} / \mathrm{m}^{2}$ ).

\section{Effect of weed management on plant height}

Data recorded on plant height at different growth stages $(15,30$ and 45 DAT) were statistically analysed and presented in Table 2. From all the observations it was found that at 15 and 30 DAT, weed free plots recorded highest plant height due to no crop weed competition throughout the crop growth period. Repeated weeding led to better aeration and non occurrence of toxic gases which improve the crop growth. The lowest plant height was observed under unweeded control plots. In unweeded control, the weeds were allowed to grow uninterruptedly throughout the crop growth period. It resulted in maximum crop weed competition for growth resources since beginning resulting minimum height of rice plants. Among different chemical weed control treatments Pyrazosulfuron ethyl $25 \mathrm{~g} / \mathrm{ha}$ as pre- emergence $f b$ hand weeding at 40 DAT recorded highest plant height. Pyrazosulfuron ethyl controls the weeds more efficiently than Oxadiargyl and Pretilachlor as the result the growth resources were more available to the plants in Pyrazosulfuron ethyl treated plots (Banerjee et al., 2005).

\section{Effect of weed management on LAI}

In all the observations (Table 2) the highest LAI was observed in weed free treatment which may be due to lowest crop-weed competition in that plot. The lowest LAI was found in unweeded control plots. There weed free plot varied significantly from that of the control plot. Leaf Area Index was found in the trend of weedfree $>$ hand weeding at 20 and 40 DAT > Pyrazosulfuron ethyl $25 \mathrm{~g} / \mathrm{ha}$ as pre-emergence $f b$ hand weeding at 40 DAT in 15 and 30 DAT and weedfree > Pyrazosulfuron ethyl $25 \mathrm{~g} / \mathrm{ha}$ as preemergence $f b$ hand weeding at 40 DAT > hand weeding at 20 and $40 \mathrm{DAT}$, found at 45 DAT. Pyrazosulfuron ethyl treated plot $\left(\mathrm{T}_{3}\right.$ and $\mathrm{T}_{6}$ ) recorded higher LAI. This might be due to its better efficacy against Oxadiargyl and Pretilachlor. Pal et al., (2012) got similar findings.

\section{Effect of weed management on dry matter accumulation $\mathrm{g} / \mathrm{m}^{2}$}

Data presented in Table 2 showed that the highest dry matter was found in weed free plot in all three crop growth stages. Among the chemically treated plots, Pyrazosulfuron ethyl $25 \mathrm{~g} / \mathrm{ha}$ as pre-emergence $f b$ hand weeding at 40 DAT shown better dry matter accumulation. The lowest plant dry matter was observed in case of unweeded control plot, as no weed control practices was practiced there; it led to minimum plant dry matter accumulation. In case of weed free plot, maximum dry matter was recorded which might be due to continuous weed 
control was followed since beginning. So no weed competition was there and better plant growth was observed. Also better aeration might be lead to maximum dry matter production. Pyrazosulfuron ethyl treated plots $\left(\mathrm{T}_{3}\right.$ and $\mathrm{T}_{6}$ ) recorded higher dry matter among the chemically controlled plots, which might be due to lower weed competition and dry weight of weeds that lead to more nutrient availability to plants and higher growth parameter and ultimately higher dry matter accumulation as compared to Oxadiargyl $\left(\mathrm{T}_{2}\right.$ and $\left.\mathrm{T}_{5}\right)$ and Pretilachlor $\left(\mathrm{T}_{1}\right.$ and $\left.\mathrm{T}_{4}\right)$.

Effect of weed management on crop growth rate

The CGR value (Table 3) at 15-30 DAT varied from $10.85 \mathrm{~g} / \mathrm{m}^{2} /$ day to a maximum of $14.31 \mathrm{~g} / \mathrm{m}^{2} /$ day. The highest CGR value at 15 - 30 DAT recorded in weed free treatment and lowest in unweeded control plot. In case of weed free plot highest CGR was recorded which was might be due to no crop weed competition. In case of unweeded control more crop weed competition was there so minimum crop growth rate was observed. At 30-45 DAT CGR value varied from a minimum of $12.96 \mathrm{~g} / \mathrm{m}^{2} /$ day in Pretilachlor $500 \mathrm{~g} / \mathrm{ha}$ as pre-emergence to $19.39 \mathrm{~g} / \mathrm{m}^{2} /$ day in Oxadiargyl $90 \mathrm{~g} / \mathrm{ha}$ as pre-emergence $f b$ hand weeding at $40 \mathrm{DAT}$.

\section{Effect of weed management on grain yield} of rice

The yield data presented in Table 3 depicted that weed control treatments significantly affect the grain yield of transplanted kharif rice. Unweeded control plot produced lowest grain yield (3.33 t/ha) which was significantly lower than all weed control treatments.

Table.1 Effect of weed management on dry weight of weeds $\left(\mathrm{g} / \mathrm{m}^{2}\right)$

\begin{tabular}{|c|c|c|c|}
\hline \multirow[t]{2}{*}{ Treatments } & \multicolumn{3}{|c|}{ Dry weight of total weeds $\left(\mathrm{g} / \mathrm{m}^{2}\right)$} \\
\hline & 20DAT & 40DAT & 60 DAT \\
\hline $\mathrm{T}_{1}($ Pretilachlor $500 \mathrm{~g} / \mathrm{ha}$ as pre-emergence $)$ & $\begin{array}{c}1.48 \\
(1.71)\end{array}$ & $\begin{array}{l}1.81 \\
(2.76)\end{array}$ & $\begin{array}{c}2.10 \\
(3.90)\end{array}$ \\
\hline$T_{2}($ Oxadiargyl 90g/ha as pre-emergence) & $\begin{array}{c}1.23 \\
(1.01)\end{array}$ & $\begin{array}{l}1.63 \\
(2.18)\end{array}$ & $\begin{array}{c}1.98 \\
(3.41)\end{array}$ \\
\hline $\begin{array}{l}T_{3}(\text { Pyrazosulfuron ethyl } 25 \mathrm{~g} / \mathrm{ha} \text { as pre- } \\
\text { emergence) }\end{array}$ & $\begin{array}{l}1.08 \\
(0.67)\end{array}$ & $\begin{array}{c}1.47 \\
(1.65)\end{array}$ & $\begin{array}{c}1.88 \\
(3.02)\end{array}$ \\
\hline $\begin{array}{l}\mathrm{T}_{4} \text { (Pretilachlor } 500 \mathrm{~g} / \mathrm{ha} \text { as pre-emergence } f b \\
\text { hand weeding at } 40 \mathrm{DAT})\end{array}$ & $\begin{array}{l}1.35 \\
(1.33)\end{array}$ & $\begin{array}{l}1.80 \\
(2.74)\end{array}$ & $\begin{array}{c}1.51 \\
(1.79)\end{array}$ \\
\hline $\begin{array}{l}T_{5}(\text { Oxadiargyl } 90 \mathrm{~g} / \mathrm{ha} \text { as pre-emergence } f b \text { hand } \\
\text { weeding at } 40 \mathrm{DAT}) \text { ) }\end{array}$ & $\begin{array}{c}1.15 \\
(70.83)\end{array}$ & $\begin{array}{l}1.64 \\
(2.21)\end{array}$ & $\begin{array}{c}1.48 \\
(1.68)\end{array}$ \\
\hline $\begin{array}{l}\text { T}_{6}(\text { Pyrazosulfuron ethyl } 25 \mathrm{~g} / \mathrm{ha} \text { as pre- } \\
\text { emergence } f b \text { hand weeding at } 40 \mathrm{DAT})\end{array}$ & $\begin{array}{c}1.07 \\
(0.64)\end{array}$ & $\begin{array}{c}1.27 \\
(1.10)\end{array}$ & $\begin{array}{c}1.29 \\
(1.15)\end{array}$ \\
\hline $\mathrm{T}_{7}($ Hand weeding at $20 \& 40 \mathrm{DAT})$ & $\begin{array}{l}1.07 \\
(0.65)\end{array}$ & $\begin{array}{c}1.19 \\
(0.91)\end{array}$ & $\begin{array}{c}1.32 \\
(1.25)\end{array}$ \\
\hline $\mathbf{T}_{8}$ (Weed free) & $\begin{array}{c}0.71 \\
(0.00)\end{array}$ & $\begin{array}{c}0.71 \\
(0.00)\end{array}$ & $\begin{array}{c}0.71 \\
(0.00)\end{array}$ \\
\hline $\mathbf{T}_{9}$ (Unweeded control) & $\begin{array}{c}2.32 \\
(4.89)\end{array}$ & $\begin{array}{c}3.77 \\
(13.74)\end{array}$ & $\begin{array}{c}4.12 \\
(16.52)\end{array}$ \\
\hline S.Em $( \pm)$ & 0.04 & 0.03 & 0.03 \\
\hline CD at $5 \%$ & 0.12 & 0.09 & 0.09 \\
\hline $\mathrm{CV}(\%)$ & 5.43 & 2.98 & 2.74 \\
\hline
\end{tabular}


Table.2 Effect of weed management on Plant height $(\mathrm{cm})$, Leaf Area Index (LAI) and Plant dry matter accumulation $\left(\mathrm{g} / \mathrm{m}^{2}\right)$

\begin{tabular}{|c|c|c|c|c|c|c|c|c|c|}
\hline \multirow[t]{2}{*}{ Treatments } & \multicolumn{3}{|c|}{ Plant height (cm) } & \multicolumn{3}{|c|}{ LAI } & \multicolumn{3}{|c|}{$\begin{array}{l}\text { Dry matter accumulation } \\
\qquad(\mathrm{g} / \mathbf{m} 2)\end{array}$} \\
\hline & 15DAT & 30DAT & 45DAT & $15 \mathrm{DAT}$ & 30DAT & $45 \mathrm{DAT}$ & $15 \mathrm{DAT}$ & 30DAT & 45DAT \\
\hline $\begin{array}{l}T_{1}(\text { Pretilachlor } 500 \mathrm{~g} / \mathrm{ha} \text { as pre- } \\
\text { emergence) }\end{array}$ & 41.17 & 70.38 & 90.83 & 1.92 & 3.10 & 3.45 & 39.89 & 215.38 & 413.17 \\
\hline $\begin{array}{l}\mathrm{T}_{2} \text { (Oxadiargyl } 90 \mathrm{~g} / \mathrm{ha} \text { as pre- } \\
\text { emergence) }\end{array}$ & 42.19 & 70.69 & 91.81 & 2.18 & 3.17 & 3.51 & 41.32 & 223.22 & 417.67 \\
\hline $\begin{array}{l}T_{3}(\text { Pyrazosulfuron ethyl } 25 \mathrm{~g} / \mathrm{ha} \text { as } \\
\text { pre-emergence) }\end{array}$ & 42.24 & 71.09 & 93.01 & 2.39 & 3.30 & 3.60 & 43.44 & 236.64 & 486.33 \\
\hline $\begin{array}{l}T_{4}(\text { Pretilachlor } 500 \mathrm{~g} / \mathrm{ha} \text { as pre- } \\
\text { emergence } f b \text { hand weeding at } 40 \\
\text { DAT) }\end{array}$ & 41.21 & 70.09 & 94.13 & 1.86 & 3.04 & 3.92 & 39.86 & 219.76 & 508.00 \\
\hline $\begin{array}{l}T_{5}(\text { Oxadiargyl } 90 \mathrm{~g} / \mathrm{ha} \text { as pre- } \\
\text { emergence } f b \text { hand weeding at } 40 \\
\text { DAT }) \text { ) }\end{array}$ & 42.13 & 70.78 & 94.24 & 2.29 & 3.44 & 4.01 & 43.22 & 220.36 & 511.22 \\
\hline $\begin{array}{l}T_{6}(\text { Pyrazosulfuron ethyl } 25 \mathrm{~g} / \mathrm{ha} \text { as } \\
\text { pre-emergence } f b \text { hand weeding at } \\
40 \text { DAT })\end{array}$ & 42.50 & 71.47 & 95.33 & 2.38 & 3.50 & 4.18 & 52.89 & 248.89 & 513.44 \\
\hline $\mathrm{T}_{7}($ Hand weeding at $20 \& 40 \mathrm{DAT})$ & 42.71 & 72.06 & 91.69 & 2.50 & 3.68 & 4.17 & 42.00 & 247.67 & 486.56 \\
\hline$T_{8}($ Weed free $)$ & 45.90 & 75.07 & 94.46 & 2.77 & 3.75 & 4.23 & 62.78 & 277.47 & 550.61 \\
\hline $\mathbf{T}_{9}$ (Unweeded control) & 39.90 & 68.27 & 90.81 & 1.79 & 2.90 & 3.36 & 41.67 & 204.45 & 404.39 \\
\hline S.Em $( \pm)$ & 0.85 & 0.64 & 0.98 & 0.18 & 0.09 & 0.12 & 3.98 & 3.71 & 20.32 \\
\hline CD at $5 \%$ & 2.55 & 1.91 & 2.94 & 0.53 & 0.27 & 0.37 & 11.93 & 11.13 & 60.90 \\
\hline $\mathrm{CV}(\%)$ & 3.49 & 1.55 & 1.83 & 13.72 & 4.68 & 5.59 & 15.23 & 2.76 & 7.38 \\
\hline
\end{tabular}


Table.3 Effect of weed management on Crop Growth Rate $\left(\mathrm{g} / \mathrm{m}^{2} /\right.$ day)

\begin{tabular}{|c|c|c|c|}
\hline \multirow[t]{2}{*}{ Treatments } & \multicolumn{2}{|c|}{$\operatorname{CGR}\left(\mathrm{g} / \mathrm{m}^{2} /\right.$ day $)$} & \multirow{2}{*}{$\begin{array}{c}\text { Grain yield } \\
(t / h a)\end{array}$} \\
\hline & 15-30 DAT & 30-45DAT & \\
\hline$T_{1}$ (Pretilachlor $500 \mathrm{~g} / \mathrm{ha}$ as pre-emergence) & 11.70 & 13.19 & 3.93 \\
\hline$T_{2}$ (Oxadiargyl 90g/ha as pre-emergence) & 12.13 & 12.96 & 4.01 \\
\hline $\begin{array}{l}T_{3} \text { (Pyrazosulfuron ethyl } 25 \mathrm{~g} / \text { ha as pre- } \\
\text { emergence) }\end{array}$ & 12.88 & 16.65 & 4.12 \\
\hline $\begin{array}{l}\mathrm{T}_{4} \text { (Pretilachlor } 500 \mathrm{~g} / \mathrm{ha} \text { as pre-emergence } \\
f b \text { hand weeding at } 40 \mathrm{DAT})\end{array}$ & 11.99 & 19.22 & 4.56 \\
\hline $\begin{array}{l}T_{5}(\text { Oxadiargyl } 90 \mathrm{~g} / \mathrm{ha} \text { as pre-emergence } f b \\
\text { hand weeding at } 40 \mathrm{DAT}) \text { ) }\end{array}$ & 11.81 & 19.39 & 4.90 \\
\hline $\begin{array}{l}T_{6}(\text { Pyrazosulfuron ethyl } 25 \mathrm{~g} / \mathrm{ha} \text { as pre- } \\
\text { emergence } f b \text { hand weeding at } 40 \mathrm{DAT})\end{array}$ & 13.07 & 17.64 & 5.22 \\
\hline$T_{7}($ Hand weeding at $20 \& 40$ DAT $)$ & 13.71 & 15.93 & 5.12 \\
\hline$T_{8}$ (Weed free) & 14.31 & 18.21 & 5.41 \\
\hline$T_{9}$ (Unweeded control) & 10.85 & 13.33 & 3.33 \\
\hline $\operatorname{S.Em}( \pm)$ & 0.37 & 1.34 & 0.13 \\
\hline CD at $5 \%$ & 1.12 & 4.02 & 0.39 \\
\hline CV(\%) & 5.17 & 14.25 & 5.02 \\
\hline
\end{tabular}

Grain yield was recorded highest of 5.41 t/ha (62.46\% increase over control) in weed free treatment, due to lowest crop-weed competition. Pyrazosulfuron ethyl $25 \mathrm{~g} / \mathrm{ha}$ as pre-emergence $f b$ hand weeding at 40 DAT and Hand weeding at 20 and 40 DAT produced $5.22 \mathrm{t} / \mathrm{ha}$ and $5.12 \mathrm{t} / \mathrm{ha}$ grain yield respectively which were at par with the weed free treatment. It was also observed that hand weeding at 40 DAT increased the grain yield over sole application of chemical weed control methods.

In conclusion, weeds are a major constraint in transplanted kharif rice. The present study has revealed that different weed management practices affect the plant growth parameters significantly. Although hand weeding was the most favorable mean of plant growth Pyrazosulfuron ethyl $25 \mathrm{~g} / \mathrm{ha}$ as preemergence $f b$ hand weeding at 40 DAT was found good among different combined means of weed management practices.

\section{References}

Banerjee, P., Dutta, D., Biswas, S., Bandyopadhyay, P. and Maiti, D. 2005. Effect of irrigation and weed management on weed growth and yield performance of transplanted hybrid rice. Journal of Crop and Weed 1 (2): 20-22.

Cochran, W. G. and Cox, G. M., 1957, Experimental design. 2nd Edition, John Willey and Sons, Inc. New York, p. 615.

Maheswari, M. D., A. S. Rao, P. Prasuna Rani and B. Venkateswarlu. 2015. Effect of Weed Management 5Practices on Growth and Economics of Transplanted Rice. International Journal of Pure and Applied Bioscience, 3(3): 113-116.

Murali, A. P. and S. Gowthami. 2017. Early Post Emergence Herbicide and Their Influence on Weed Population Dynamics in Transplanted Rice 
(Oryza Sativa L.). Chemical Science and Review Letter, 6(21): 561-566.

Pal, S., Ghosh, R.K., Banerjee, H., Kundu, R. and Alipatra, A. 2012. Effect of pyrazosulfuron-ethyl on yield of transplanted rice. Indian Journal of Weed Science 44(4): 210-213.

Rodder W. 2001. Slash and burn rice systems in the hills of Northern Lao PDR. In. Description, challenges and opportunities IRRI, LOS Banos, Philippines, $201 \mathrm{pp}$.

Singh, YG, Singh V.P., Singh, P., Shrivastava, R.S.I., Saxena, A., Mortimer, M., Johnson, D.E., and White J.L. 2002. Effect of different establishment methods on rice-wheat and the implication of weed management in Indo-Gangetic Plains. In. proceedings of the International workshop on Herbicide Resistance management and zero tillage in Ricewheat cropping system, 4-6 March 2002. Department of Agronomy, CCS Hryana Agricultural University, Hisar, India, pp.188-192.

Sureshkumar, R. and Durairaj. 2016. Weed characters and indices of transplanted rice as influenced by different weed management practices. International Journal of Agriculture Sciences. 8(51): 2221-2223.

\section{How to cite this article:}

Nirmala Patel and Pritam Ghosh. 2019. Yield Improvement of Kharif Rice by Different Weed Management Practices. Int.J.Curr.Microbiol.App.Sci. 8(03): 346-352.

doi: https://doi.org/10.20546/ijcmas.2019.803.043 